Original scientific paper

\title{
Selecting tree species for reclamation of coal mine tailings based on physiological parameters
}

\author{
Srđan Stojnići ${ }^{*}$, Mirjana Bojoviće ${ }^{2}$ Andrej Pilipović́ ${ }^{1}$, Saša Orlović ${ }^{1}$ \\ 1 University of Novi Sad, Institute of Lowland Forestry and Environment, Novi Sad, Serbia \\ 2 Educons University, Faculty of Ecological Agriculture, Sremska Kamenica, Serbia \\ * Corresponding author: Srđan Stojnić; E-mail: srdjan.stojnic@uns.ac.rs
}

Received: 9 Jun 2021; Revised: 18 Jun 2021; Accepted: 22 Oct 2021

\begin{abstract}
In the present study we compared the physiological performances of Prunus avium L., Robinia pseudoacacia L., Juglans nigra L., and Populus x euramericana cl. Pannonia, planted at the coal mine tailings of the Mining Basin "Kolubara" (Serbia), to assess the potential of different tree species for land reclamation. The measurements were conducted during three consecutive years characterized by contrasting climatic conditions (wet and drought). The results showed that the rate of net photosynthesis $(\mathrm{A})$, stomatal conductance $\left(\mathrm{g}_{\mathrm{s}}\right)$ and transpiration rate (E) sharply declined in two dry years in all tree species. These trends were particularly evident for R. pseudoacacia and J. nigra, in which $\mathrm{A}, \mathrm{g}_{\mathrm{s}}$ and $\mathrm{E}$ were twice as low during the dry years. On the other hand, R. pseudoacacia and $P . \mathrm{x}$ euramericana $\mathrm{cl}$. Pannonia seedlings were characterized by the highest water-use efficiency and intrinsic water-use efficiency during the dry years, indicating that these species are more efficient responders to drought, due to their ability to maintain a balance between the loss of water and the $\mathrm{CO}_{2}$ assimilation rates. The survival rate of the examined tree species was high $(>86 \%)$ and increased in the following order: $P$. avium $<J$. nigra $<R$. pseudoacacia $<P$. x euramericana cl. Pannonia. Based on the obtained results we recommend R. pseudoacacia and P. x euramericana cl. Pannonia as a good solution for afforestation and revitalization of degraded habitats, such as coal mine tailings, although high survival rate, observed in P. avium and J. nigra, makes these two species a candidate for planting during degraded sites reclamation, as well.
\end{abstract}

Keywords: coal mine tailings, afforestation, reclamation, tree species, gas exchange.

\section{Introduction}

Coal exploitation for energy production has been widely present in central and eastern Europe, generating a large amount of waste deposited at the soil surface (Pietrzykowski, 2019). Such established post-mining landscapes strongly disturb all the components of the ecosystem, including soil, water and vegetation cover (Hamidović et al. 2013). As a consequence of large-scale ecosystem disturbances, these sites frequently face problems undergoing secondary community succession and forest reestablishment (Hall et al. 2019).

Establishing a permanent forest cover presents a common approach in mine reclamation programmes (Carter and Ungar, 2002). In principle, three restoration methods might be considered for such degraded lands: (1) spontaneous vegetation succession, (2) planting of suitable tree species or (3) 
combining both (Prach, 2003). Although spontaneous natural succession should be considered in all cases, establishing natural forests through this process can take decades or even centuries (Angel et al. 2009). On the other hand, planting of trees may provide a rapid vegetation cover, thereby accelerating natural succession and restoring ecosystem functions in the shorter period of time (Pang et al. 2020). For example, having compared different reforestation treatments across 10 mine sites, five years after their reclamation, Auch et al. (2005) reported that natural invasion produced only 7 trees per ha, in comparison to planting of nursery seedlings, which produced between 783 and 930 trees per ha, depending on tree species and site conditions.

However, mine reclamation is usually challenging, particularly due to poor and highly changeable soil physical and chemical properties (Sena et al. 2018). In such habitat conditions planted trees are frequently exposed to severe environmental conditions, which notably affect their growth and survival. Hence, the success of reforestation largely depends on the adaptation potential of the tree species to unfavourable growth conditions of reclaimed mine soils (Pietrzykowski, 2019).

Trees may acclimate to adverse site conditions in a number of ways, including physiological responses and modulation in anatomy and morphology (Kesić et al. 2020). Physiological adjustment occurs inside plant cells and organs in response to external signals, resulting in the improved capacity of plants to cope with environmental changes. These mechanisms commonly include stomatal control of water loss, leaf water potential, osmotic adjustment, and photosynthetic carbon sequestration (Thomas and Gausling, 2000; Bojović et al. 2017; Deligöz and Bayar, 2018). Recent studies have demonstrated different ability of tree species to respond to abiotic stress (Stojnić et al. 2016; Vastag et al. 2019), indicating that the planning of reforestation, and the selection of suitable planting material for this purpose, accordingly, should be closely related to the understanding of the physiological response of trees to extreme growth conditions.

In the present research we studied the physiological performances of four temperate broadleaved tree species (Populus x euramericana ((Dode) Guinier) cl. Pannonia, Robinia pseudoacacia L., Juglans nigra L., Prunus avium L.), grown at coal mine tailings, during three successive years characterized by contrasting climatic conditions. The selection of the above tree species for coal mine reclamation was made on the basis of previous knowledge concerning their ecology and growth requirements, as well as available literature dealing with the use of different tree species for this purpose. Due to the ability to fix nitrogen symbiotically, R. pseudoacacia has been broadly used for waste land and surface-mine reclamation. Certain studies showed that symbiotic nitrogen fixation of this species positively affected nitrogen and carbon accumulation, influencing also initial soil formation at coal mines (Keskin and Makineci, 2009). P. avium is a pioneer tree species, able to rapidly colonize open fields by seeds and suckering, therefore contributing secondary succession to woodlands (Russell, 2003). In addition, as the seeds of $P$. avium are commonly disseminated over large distances by birds, this species can efficiently contribute to spontaneous reclamation of landfill sites by establishing a group of trees to attract avian seed dispersers (Robinson and Handel, 1993). Indeed, the same authors documented that the majority of woody seedlings found at the landfill site originated from fleshyfruited, bird-dispersed plants. J. nigra has been showing good performances on surface mined areas, thus it is widely planted throughout United States (Andersen et al. 1989; Angel et al. 2006). P. x euramericana cl. Pannonia (also known as cl. M-1) has been widely used poplar clone in practice due to good rooting ability and survival rate (Kovačević et al. 2009). For the same reasons, this clone has been frequently used as a control clone in the experiments aimed at testing newly selected clones in Serbia (Pilipović et al. 2012; Galović et al. 2020).

Hance, the aim of the research was to select tree species showing high potential for reclamation of coal mine tailings based on their physiological performances. We hypothesized that the selected tree species would demonstrate different performances in response to unfavourable environmental conditions of the mine landfill site, especially during years characterized by water scarcity, therefore facilitating identification of those species that might be potentially used in mine reclamations programmes. 


\section{Material and methods}

\subsection{Research area and plant material}

The experiment was established on the coal mine tailing of the Mining Basin "Kolubara" (Serbia), "Tamnava - Zapadno Polje" (N 44 $30^{\circ}$ ', E 20¹2') in the spring of 2010, from one-year-old rooted cuttings of $P$. x euramericana cl. Pannonia (690 rooted cuttings), one-year-old seedlings of $R$. pseudoacacia (1475 seedlings) and J. nigra (297 seedlings), and two-year-old seedlings of $P$. avium (1080 seedlings). The bareroot seedlings were planted in the holes $60 \mathrm{~cm}$ deep, made by the tractor drill, with $4 \times 4 \mathrm{~m}$ spacing. The soil at the experimental site belongs to the texture class of sandy loam soils, with a large share of total sand (62\%, on average) and moderate share of silt (24\%). The soil $\mathrm{pH}$ value ranged between 6.35 and 7.05, whereas the $\mathrm{CaCO}_{3}$ content varied between 3.4 and $3.9 \mathrm{mg} / 100 \mathrm{~g}$ (Stojnić et al. 2011).

The climate records (monthly values of mean air temperatures and sum of precipitations) were

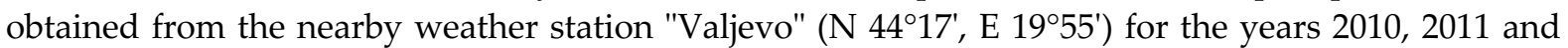
2012, respectively (Republic Hydrometeorological Service of Serbia 2010, 2011, 2012).

The survival rate (\%) of the seedlings was determined at the end of 2011 by counting all living trees on the experimental plot and comparing with the number of initially planted seedlings.

\subsection{Measurements of physiological parameters}

Measurements of physiological parameters were conducted in the mid of August of 2010, 2011 and 2012, considering that it is characterized by the smallest amount of precipitation and the plants are therefore most exposed to drought stress during this month. The ADC Bioscientific Ltd. LCpro+ portable photosynthesis measuring system was used for the recording of net $\mathrm{CO}_{2}$ assimilation rate (A [ $\left.\mu \mathrm{mol} \mathrm{m} \mathrm{m}^{-2} \mathrm{~s}^{-1}\right]$ ), transpiration (E [mmol m $\left.\mathrm{m}^{-2} \mathrm{~s}^{-1}\right]$ ) and stomatal conductance ( $\mathrm{g}_{\mathrm{s}}\left[\mathrm{mol} \mathrm{m} \mathrm{m} \mathrm{s}^{-1}\right]$ ). Measurements were conducted in clear, sunny weather, between 09:00 and 11:00 a.m. The irradiance level inside the leaf chamber was set on $1000 \mu \mathrm{mol} \mathrm{m}^{-2} \mathrm{~s}^{-1}$, whereas $\mathrm{CO}_{2}$ concentration, air temperature and air humidity were taken ambient from the surrounding atmosphere. Water-use efficiency (WUE $\left[\mu \mathrm{mol} \mathrm{mmol}^{-1}\right]$ ) was calculated as the ratio of net $\mathrm{CO}_{2}$ assimilation rate and transpiration rate (Farquhar et al. 1989), whereas intrinsic water-use efficiency (WUEi $\left[\mu \mathrm{mol} \mathrm{mol}^{-1}\right]$ ) was computed as the ratio of net $\mathrm{CO}_{2}$ assimilation rate to stomatal conductance (Farquhar et al. 1989). The measurements were performed on 10 plants per species. One leaf per plant was used for the records of leaf gas exchange.

\subsection{Statistical analyses}

The data were processed using the statistical software package STATISTICA, version 13 (TIBCO Software Inc, 2017). Two-way analysis of variance (ANOVA) followed by Tukey's HSD (honestly significant difference) test were used to test the effect of tree species, year and interaction year $\mathrm{x}$ tree species on the studied physiological traits (A, E, $\mathrm{g}_{\mathrm{s}}$, WUE and WUEi). Significance was determined at $\mathrm{p}<0.05$ throughout.

\section{Results}

\subsection{Climatic conditions during years}

Mean air temperature was slightly higher in $2012\left(12.7^{\circ} \mathrm{C}\right)$ than in $2011\left(11.9^{\circ} \mathrm{C}\right)$ and $2010\left(11.9^{\circ} \mathrm{C}\right)$. However, during the growing season (March-September) mean air temperatures considerably increased across the observed years and amounted to 16.9, 17.6 and $18.7^{\circ} \mathrm{C}$ in 2010, 2011 and 2012, respectively (Figure 1).

The total rainfall during the growing season of 2010 was $754 \mathrm{~mm}$, while for the same period of 2011 and 2012 it was only 411 and 291 mm, respectively (Figure 1). Moreover, considering only the 
precipitations during August, when the measurements of gas exchange were made, we may speculate that the plants were exposed to severe drought stress in 2011 and 2012 (the precipitation sums amounted only to 0.5 and $2.3 \mathrm{~mm}$, respectively), whereas 2010 was characterized by more suitable conditions for plant growth, since the total rainfall was slightly lower $(59.6 \mathrm{~mm})$ than the 30-year average. Similarly, mean air temperatures during August of 2010, 2011 and 2012 were higher than the 30 -year average for this month and progressed continuously, amounting to $22.2,23.6$ and $24.8^{\circ} \mathrm{C}$, respectively.
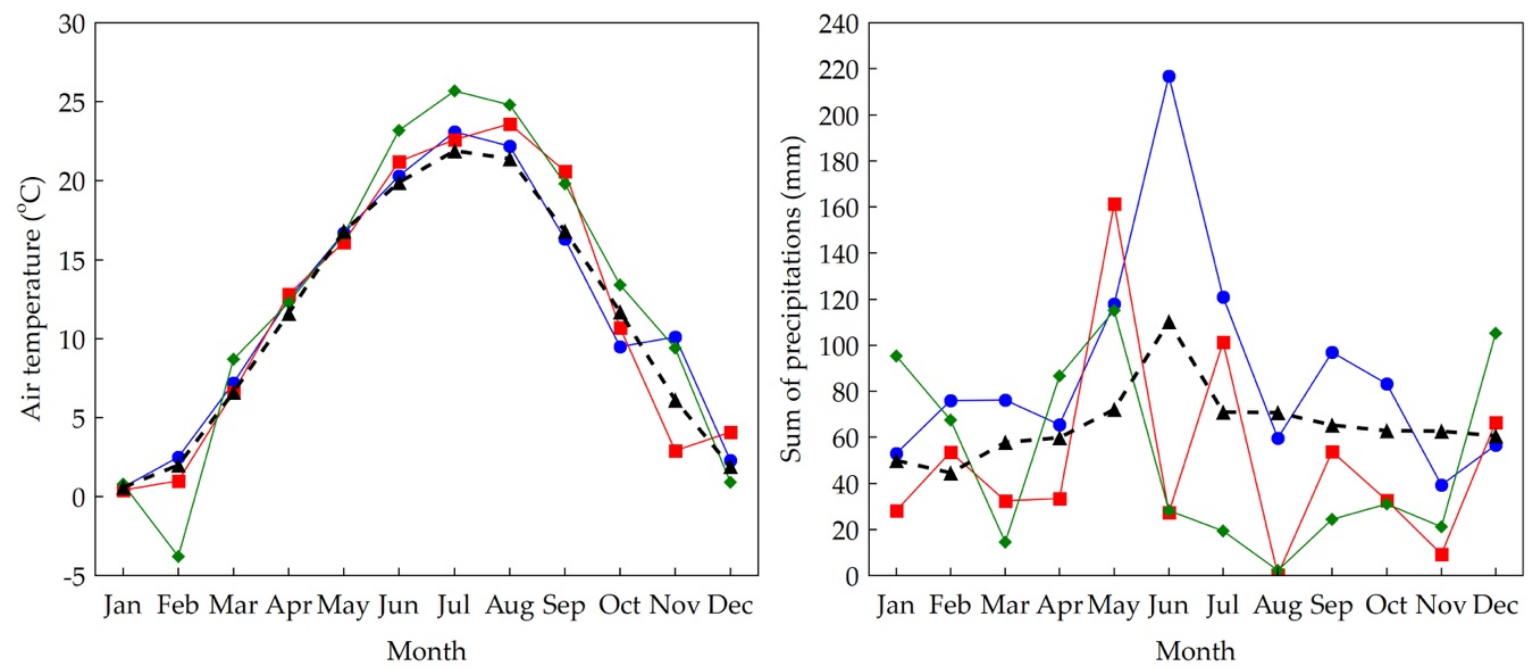

year: 2010; $\square$ year: 2011; $\gg$ year: 2012;

mean 1981-2010

Figure 1. Monthly mean air temperatures $\left({ }^{\circ} \mathrm{C}\right)$ and sums of precipitations $(\mathrm{mm})$ in 2010, 2011, 2012 and the period 1981-2010. The data were obtained from the weather station "Valjevo" (source: Republic Hydrometeorological Service of Serbia, 2010, 2011, 2012).

\subsection{Survival rate}

Average survival rate at the end of 2011 was high and amounted to $93.7 \%$. The highest survival rate was recorded in P. x euramericana cl. Pannonia (99.6\%), while the lowest was in P. avium (86.1\%). The survival rates of J. nigra and R. pseudoacacia were similar and amounted to $93.6 \%$ and $95.5 \%$, respectively.

\subsection{Physiological performances of tree species}

Physiological performances of the studied tree species were notably influenced by the climatic conditions over the years. Likewise, significant differences were found among the tree species regarding all investigated parameters. The interaction between tree species and years was significant for all traits, as well (Table 1).

Table 1. Results of Two-way ANOVA procedure for the observed physiological parameters assessed during three consecutive years (2010, 2011 and 2012).

\begin{tabular}{|c|c|c|c|c|c|c|c|c|c|c|c|}
\hline \multirow{2}{*}{ Effect } & \multirow{2}{*}{$\mathrm{df}$} & \multicolumn{2}{|c|}{ A } & \multicolumn{2}{|c|}{$g_{s}$} & \multicolumn{2}{|c|}{ E } & \multicolumn{2}{|c|}{ WUE } & \multicolumn{2}{|c|}{ WUEi } \\
\hline & & $\mathbf{F}$ & $\mathrm{p}$ & $\mathbf{F}$ & $\mathbf{p}$ & $\mathbf{F}$ & $\mathbf{p}$ & $\mathbf{F}$ & $p$ & $\mathbf{F}$ & $p$ \\
\hline Year (Y) & 2 & 203.6 & $<0.001$ & 236.1 & $<0.001$ & 190.9 & $<0.001$ & 32.6 & $<0.001$ & 19.7 & $<0.001$ \\
\hline Species (S) & 3 & 133.6 & $<0.001$ & 42.7 & $<0.001$ & 126.8 & $<0.001$ & 34.6 & $<0.001$ & 15.8 & $<0.001$ \\
\hline$Y \times S$ & 6 & 8.5 & $<0.001$ & 10.4 & $<0.001$ & 21.6 & $<0.001$ & 8.4 & $<0.001$ & 7.0 & $<0.001$ \\
\hline
\end{tabular}


Maximum A, $g_{s}$ and $E$ were recorded in 2010, followed by a significant decline $(p<0.001)$ during 2011 and 2012 in all tree species (Figure 2).
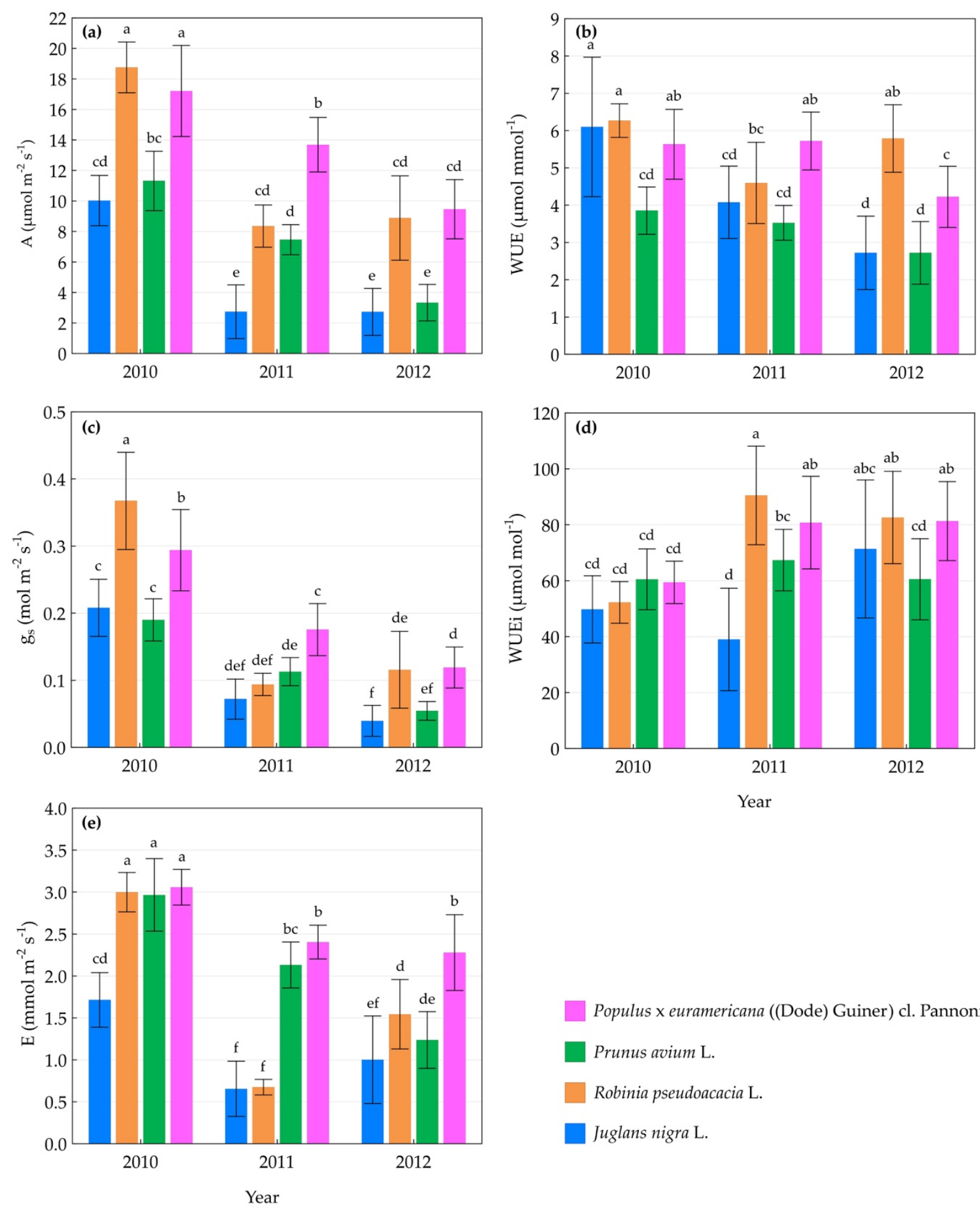

Populus x euramericana ((Dode) Guiner) cl. Pannonia

Prunus avium $\mathrm{L}$.

Robinia pseudoacacia L.

Juglans nigra L.

Figure 2. Net $\mathrm{CO}_{2}$ assimilation rate (A), water use efficiency (WUE), stomatal conductance ( $\mathrm{g}_{\mathrm{s}}$ ), intrinsic water-use efficiency (WUEi) and transpiration (E) in the studied tree species grown at the coal mine tailing "Tamnava - Zapadno Polje" during 2010, 2011 and 2012.

A particularly sharp decline in the aforementioned traits was observed in R. pseudoacacia and $J$. nigra during 2011 (more than 50\%). Nevertheless, R. pseudoacacia was the only species in which A, $g_{s}$ and E had higher values in 2012, compared to 2011, showing signs of acclimation to water scarcity. 
Likewise, the same species was characterized by the highest values of WUEi during two dry years (90.5 and $82.6 \mu \mathrm{mol} \mathrm{mol}^{-1}$, respectively), and WUE, during $2012\left(5.72 \mu \mathrm{mol} \mathrm{mmol}^{-1}\right)$ (Figure $2 \mathrm{~b}$ and $2 \mathrm{~d}$ ). It is worth mentioning that apart from R. pseudoacacia, high values of WUE and WUEi, during the years with limited water availability, were also recorded in the seedlings of $P$. x euramericana cl. Pannonia.

\section{Discussion}

Considering available data about soil properties at the coal mine tailing "Tamnava - Zapadno Polje", it might be assumed that the topsoil (i.e. the surface layer of the soil) is characterized by favourable physical properties ( $62 \%$ of sand, $24 \%$ of silt) and $\mathrm{pH}(6.70$, on average) for tree growth. The study by Sena et al. (2015) showed that tree growth and survival, two years after experimental plot installation, were the highest on the soil characterized by $60 \%$ sand and $27 \%$ silt share, in comparison to soils with a higher share of sand (73-78\%) and lower share of silt (6.5-7.7\%). Likewise, Burger et al. (2017) found that the productivity of trees grown at mine lands is the highest on soils with sandy loam texture and $\mathrm{pH}$ between 5.0 and 7.0.
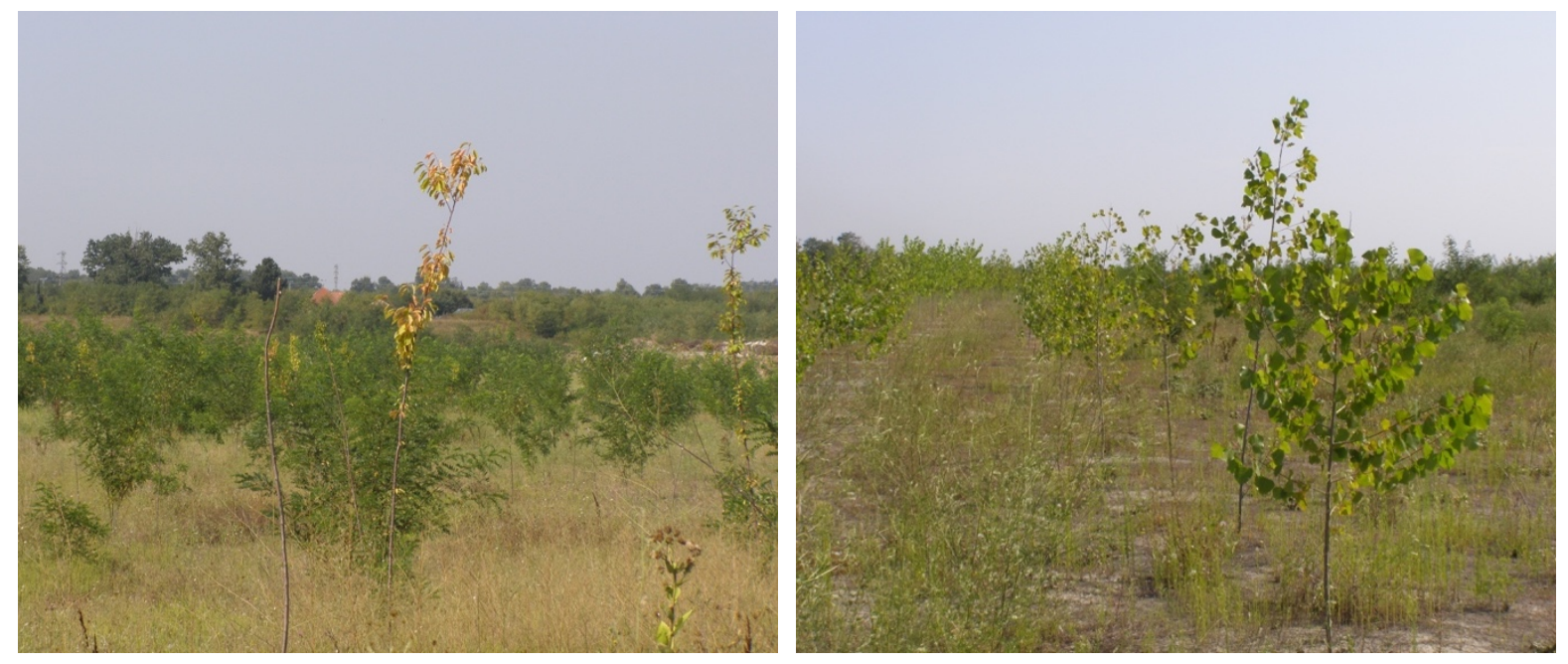

Figure 3. P. avium and R. pseudoacacia (left) and P. x euramericana cl. Pannonia (right) seedlings grown at the coal mine tailing "Tamnava - Zapadno Polje" during the growing season of 2011. Photo by Dr Andrej Pilipović (date: 30th August, 2011).

A number of studies have shown that environmental factors, particularly drought, may significantly affect physiological performances of tree species (Swoczyna et al. 2015; Vaz Monteiro et al. 2017). Droughts strongly influence plant distribution patterns in post-mining landscapes (Halwatura et al. 2015). According to Nurtjahya and Franklin (2017), species that have been widely adopted for mine reclamation are the ones that are tolerant to a broad spectrum of environmental conditions, in particular to low water and nutrient availability. In the present study, the investigated tree species manifested different sensitivity to contrasting climatic conditions recorded during three successive years, exhibiting different physiological performances, especially in terms of acclimation strategies for coping with stress. Thus, the effects of unfavourable environmental conditions (during the years characterized by water scarcity) should not be generalized and have to be analyzed for each species individually.

Our results showed a significant decline of A, E and $g_{s}$ in the studied tree species during dry years. A strong reduction of $\mathrm{g}_{\mathrm{s}}$ was particularly pronounced in J. nigra and $R$. pseudoacacia, which are known as isohydric tree species (Loewenstein and Pallardy, 1998; Moser et al. 2016). Likewise, besides the sharply reduced $\mathrm{g}_{\mathrm{s}}$ under drought conditions, R. pseudoacacia and P. x euramericana cl. Pannonia displayed other characteristics indicative of isohydric behaviour, such as high water-use efficiency 
(Kunz et al. 2016). This strategy allows plants strict stomatal control of transpiration in response to drought stress, therefore reducing hydraulic risks (Garcia-Forner et al. 2017). However, it may also cause carbon starvation in the conditions of prolonged and cyclical drought events, triggering even plants premature mortality in some cases (McDowell et al. 2008). A recent study conducted in the urban area of Munich showed that R. pseudoacacia trees were characterized by strong growth reduction during dry years, but also showed high drought resilience, which was reflected in a rapid recovery from drought (Moser et al. 2016). Moreover, studying drought tolerance of newly planted broadleaf street trees using chlorophyll fluorescence, Vaz Monteiro et al. (2017) found that Populus tremuloides and R. pseudoacacia experienced the largest decline of maximum quantum yield of PSII when subjected to drought stress, showing also signs of leaf wilting and dropping. The process of leaf abscission in $R$. pseudoacacia plants exposed to water stress was also reported by Veste and Kriebitzsch (2012).

As we mentioned above, in this study, R. pseudoacacia and P. x euramericana cl. Pannonia were characterized by the highest WUE and WUEi during dry years. In terms of WUEi, these results suggest that the proportional decrease in A was less than the decline of $\mathrm{g}_{\mathrm{s}}$, leading to an increase in the mentioned parameter (Pita et al. 2005). On the other hand, higher WUE values observed in the mentioned tree species during years with limited water availability (as compared to 2010) indicate that these species respond more efficiently to drought stress, as they are able to maintain a balance between A and E (according to Pliura et al. 2018). However, current knowledge on the variation of leaf gas exchange in $P . \times$ euramericana cl. Pannonia rooted cuttings grown at coal mine tailings is scarce. Although previous studies showed modest physiological performances of this clone in the poplar field trials (Orlović et al. 1998; Orlović et al. 2002), certain authors reported superior height growth and survival rate of cl. Pannonia rooted cuttings in comparison to other tested poplar clones (Andrašev et al. 2007; Kovačević et al. 2009). Likewise, several studies demonstrated good physiological response of P. x euramericana cl. Pannonia plants subjected to artificial contamination of heavy metals, oil and herbicides, indicating good phytoremediation potential of this clone (Pilipović et al. 2012; Pilipović et al. 2020).

Moreover, we found that R. pseudoacacia was the only species in which A, $\mathrm{g}_{\mathrm{s}}$ and $\mathrm{E}$ had higher values in 2012 compared to 2011, thus, we might assume that the mentioned species showed signs of acclimation to water stress. There is a general agreement that $R$. pseudoacacia has efficient acclimation mechanisms (e.g. morphological, physiological and biochemical) that are activated in response to drought stress (Xu et al. 2009; Mantovani et al. 2014). In addition, Minucci et al. (2017) reported that $R$. pseudoacacia biomass production was unaffected by different drought frequencies due to the fact that the species employed both drought tolerance and drought avoidance strategies. Lastly, studying the leaf movement and photosynthetic plasticity of R. pseudoacacia under different stress conditions, $\mathrm{Xu}$ et al. (2009) concluded that physiological and biochemical alterations can acclimatize seedlings to extended drought stress, although these protective strategies are established at the expense of losing the ability to respond rapidly to fluctuations of the environment.

The results of our study showed similarities between J. nigra and P. avium in terms of WUE, as it decreased with increasing drought intensity during the examined dry years (2011 and 2012). Having in mind that the mean air temperature during August of 2011 and 2012 progressed continuously, it was expected that as drought stress becomes severe, dehydration of mesophyll cells inhibits the process of photosynthesis, mesophyll metabolism is impaired and WUE decreases (Taiz and Zeiger, 2003). On the other hand, the obtained values for WUEi in J. nigra and P. avium in 2012 were significantly higher and without statistically significant differences compared to those in 2010, respectively, indicating an efficient intercellular utilization of $\mathrm{CO}_{2}$ under water stress (Pagter et al. 2004).

The survival rate across the studied species was high, although the results cannot be considered as fully valid since they were observed only once during the study (e.g. after the second growing season). Nevertheless, our results are similar to those reported by Sena et al. (2015) for four tree species (Fraxinus pennsylvanica, Quercus rubra, Q. alba, and Liriodendron tulipifera) grown across three spoil sites characterized by different soil properties. The survival rate of the examined tree species increased in the following order: P. avium $<$ J. nigra $<$ R. pseudoacacia $<$ P. x euramericana cl. Pannonia, indicating the 
highest ones in the tree species in which the highest WUE properties were recorded. Even though $P$. avium is essentially a pioneer species (Russell, 2003), this species had the lowest survival rate in our experiment, which might be related to its moderate tolerance to drought (Ashwood et al. 2015).

Since we did not observe either leaf or soil water potential, we may only speculate about drought impact on plants based on the meteorological data (e.g., sum of precipitations and mean air temperatures) over the studied years. Although a drier climate during 2011 and 2012 notably affected the physiological performances of all tree species, $R$. pseudoacacia and P. x euramericana cl. Pannonia showed the highest survival rate, as well as signs of acclimation to drought stress throughout conservative water use (i.e., increased water-use efficiency and intrinsic water-use efficiency). However, the use of R. pseudoacacia and P. x euramericana cl. Pannonia for monoculture establishment calls for caution, even when it comes to degraded lands reclamation. High acclimatization potential of R. pseudoacacia for growth on different habitats, as well as its high competitive ability, refer to the high invasive potential of this species (Klisz et al. 2021), especially in dry and semi-dry environments (Vítkova et al. 2017). Likewise, although it brings numerous advantages (e.g. capturing of both additive and non-additive genetic variance) (Silva et al. 2004), clonal forestry is also known for its disadvantages, among which the reduced genetic diversity, unpredictable clone by environment interaction, and negative public opinion have been frequently seen as the major issues (Harry, 2019; Ingvarsson and Dahlberg, 2019). Hence, the establishment of multiclonal plantations or mixed stands may provide various environmental and economic benefits, including greater biodiversity and resilience toward negative natural and anthropogenic influences, as well as increased stand productivity. Indeed, Andrašev et al. (2015) reported that the mixed stands of R. pseudoacacia and P. x euramericana cl. Pannonia achieved greater wood volume per hectare compared to pure poplar plantations at the age of 10 years. However, besides mixed the stands of the aforementioned species, the possibility of using other tree species in combination with R. pseudoacacia and P. x euramericana cl. Pannonia should be considered to improve the development of novel ecosystems and provide continuous ecosystem services. For example, Tani et al. (2006) demonstrated that J. nigra trees grown in the mining area of $S$. Barbara (AR, Italy) showed the best performances when associated with nitrogen-fixing species, such as Alnus cordata and R. pseudoacacia. Lastly, Horodecki et al. (2019) found that litter decomposition and, therefore, soil development at the postmining sites were higher in mixed than pure stands.

\section{Conclusions}

Our results showed a great response variability of the studied tree species to unfavourable environmental conditions of the mine landfill site. Gas exchange parameters of all species varied over the years of exploration, declining sharply during two dry years. The highest survival rates were evidenced in P. x euramericana cl. Pannonia and R. pseudoacacia (99.6\% and 95.5\%, respectively), which also showed the most conservative water use in the conditions of reduced water availability. Nevertheless, the high survival rate of seedlings of all species (over $85 \%$ ), which was registered at the end of the second vegetation, indicates that the studied tree species can be successfully used for reclamation of coal mine tailings. Hence, we believe that afforestation of degraded habitats should be based on the use of multiple tree species in order to enhance overall ecosystem functionality. Nevertheless, due to the research involving plants in the juvenile phase of development, there is a need for further and continuous monitoring of the studied species at the given mine tailing site in order to obtain more reliable information about their potential for successful reclamation of mine areas.

\section{Acknowledgement}

This study was financed by the Ministry of Education, Science and Technological Development of the Republic of Serbia (Project No: 451-03-9/2021-14/200197). 


\section{References}

1. Andersen, C.P., Bussler, B.H., Chaney, W.R., Pope, P.E., Byrnes, W.R. (1989): Concurrent establishment of ground cover and hardwood trees on reclaimed mined land and unmined reference sites. Forest Ecology and Management 28: 81-99.

2. Andrašev, S., Bobinac, M., Bauer-Živković, A. (2015): Slementi rasta i struktura srednjedobnih mešovitih kultura euroamericke topole i bagrema na fluvisolu različitog boniteta. Topola 195/196: 41-53.

3. Andrašev, S., Kovačević, B., Rončević, S., Pekeč, S., Tadin, Z. (2007): Proizvodnja sadnica euroamerickih topola (Populus $\times$ euramericana (Dode) Guinier) tipa 1/1 zavisno od rokova izrade i sadnje reznica. Topola 179/180: 45-62.

4. Angel, P., Burger, J., Davis, V., Barton, C., Bower, M., Eggerud, S., Rothman, P. (2009): The forestry reclamation approach and the measure of its success in Appalachia. Proceedings of the 2009 National Meeting of the American Society of Mining and Reclamation (ASMR), 30 May 5 June 2009, Montavesta Rd., Lexington, USA: 18-36.

5. Angel, P.N., Graves, D.H., Barton, C., Warner, R.C., Conrad, P.W., Sweigard, R.J., Agouridis, C. (2006): Surface mine reforestation research: evaluation of tree response to low compaction reclamation techniques. Proceedings from the $7^{\text {th }}$ International Conference on Acid Rock Drainage, 26-30 March, St. Louis, Missouri, USA: 45-58.

6. Ashwood, F., Albertini, A., Doick, K.J. (2015): Drought-tolerant tree species for land regeneration. BPG NOTE 20 Best Practice Guidance for Land Regeneration. The Land Regeneration and Urban Greenspace Research Group.

7. Auch, T., Burger, J.A., Mitchem, D.O. (2005): Hardwood stocking after five years on reclaimed mined land in Central Appalachia: A Preliminary Analysis. Proceedings of the 2005 National Meeting of the American Society of Mining and Reclamation (ASMR), 19-23 June 2005, Breckenridge, CO, USA: 24-39.

8. Bojović, M., Nikolić, N., Borišev, M., Pajević, S., Horák, R., Lazar Pavlović, L. Vaštag, E. (2017): The effect of drought stress and recovery on pedunculate oak populations grown in semicontrolled conditions. Topola 199-200: 194-207.

9. Burger, J., Graves, D., Angel, P., Davis, V., Zipper, C. (2017): Chapter 2: The forestry reclamation approach. In: Adams, M.B. (ed): The Forestry Reclamation Approach: guide to successful reforestation of mined lands. Gen. Tech. Rep. NRS-169. Newtown Square, PA: U.S. Department of Agriculture, Forest Service, Northern Research Station: 2-1 - 2-8.

10. Carter, C.T., Ungar, I.A. (2002): Aboveground vegetation, seed bank and soil analysis of a 31year-old forest restoration on coal mine spoil in Southeastern Ohio. The American Midland Naturalist 147: 44-59.

11. Deligöz, A., Bayar, E. (2018): Drought stress responses of seedlings of two oak species (Quercus cerris and Quercus robur). Turkish Journal of Agriculture and Forestry 42: 114-123.

12. Farquhar, G.D., Ehleringer, J.R., Hubick, K.T. (1989): Carbon isotope discrimination and photosynthesis. Annual Review of Plant Physiology and Plant Molecular Biology 40: 503-537.

13. Galović, V., Joseph, M.P., Pekeč, S., Vasić, V., Vasić, S., Szabados, L. (2020): Characterization of abiotic stress-responsive RD29B and RD17 genes in different poplar clones. Topola 206: 13-20.

14. Garcia-Forner, N., Biel, C., Savé, R., Martínez-Vilalta, J. (2017): Isohydric species are not necessarily more carbon limited than anisohydric species during drought. Tree Physiology 37: 441-455.

15. Hall, S.L., Barton, C.D., Sena, K.L., Angel, P. (2019): Reforesting Appalachian surface mines from seed: a five-year black walnut pilot study. Forests 10: 573.

16. Halwatura, D., Lechner, A. M., Arnold, S. (2015): Drought severity-duration-frequency curves: a foundation for risk assessment and planning tool for ecosystem establishment in post-mining landscapes. Hydrology and Earth System Sciences 19(2): 1069-1091. 
17. Hamidović, S., Čolo, J., Kiković, D., Krivošej, Z., Lalević, B., Milinković, M. (2013): Plant and microbial diversity in coal mine-affected soil in "Kakanj" (Bosnia and Herzegovina). Zaštita materijala 4: 403-408.

18. Harry, X.W. (2019): Benefits and risks of using clones in forestry - a review. Scandinavian Journal of Forest Research 34(5): 352-359.

19. Horodecki, P., Nowiński, M., Jagodzińsk, A.M. (2019): Advantages of mixed tree stands in restoration of upper soil layers on postmining sites: A five-year leaf litter decomposition experiment. Land Degradation \& Development 30(1): 3-13.

20. Ingvarsson, P.K., Dahlberg, H. (2019): The effects of clonal forestry on genetic diversity in wild and domesticated stands of forest trees. Scandinavian Journal of Forest Research 34(5): 370-379.

21. Kesić, L., Vuksanović, V., Karaklić, V., Vastag, E. (2020): Variation of leaf water potential and leaf gas exchange parameters of seven silver linden (Tilia tomentosa Moench) genotypes in urban environment. Topola 205: 15-24.

22. Keskin, T., Makineci, E. (2009): Some soil properties on coal mine spoils reclaimed with black locust (Robinia pceudoacacia L.) and umbrella pine (Pinus pinea L.) in AgacliIstanbul. Environmental Monitoring and Assessment 159: 407.

23. Klisz, M., Puchałka, R., Netsvetov, M., Prokopuk, Y., Vítková, M., Sádlo, J., Matisons, R., Mionskowski, M., Chakraborty, D., Olszewski, P., Wojda, T., Koprowski, M. (2021): Variability in climate-growth reaction of Robinia pseudoacacia in Eastern Europe indicates potential for acclimatization to future climate. Forest Ecology and Management 492: 119194.

24. Kovačević, B., Rončević, S., Miladinović, D., Ivanišević, P., Katanić, M. (2009): Early shoot and root growth dynamics as indicators for the survival of black poplar cuttings. New Forests 38: 177-185.

25. Kunz, J., Räder, A., Bauhus, J. (2016): Effects of drought and rewetting on growth and gas exchange of minor European broadleaved tree species. Forests 7: 239.

26. Loewenstein, N.J., Pallardy, S.G. (1998): Drought tolerance, xylem sap abscisic acid and stomatal conductance during soil drying: a comparison of canopy trees of three temperate deciduous angiosperms. Tree Physiology 18: 431-439.

27. Mantovani, D., Veste, M., Freese, D. (2014): Black locust (Robinia pseudoacacia L.) ecophysiological and morphological adaptations to drought and their consequence on biomass production and water-use efficiency. New Zealand Journal of Forestry Science 44(1): 1-11.

28. McDowell, N., Pockman, W.T., Allen, C.D., Breshears, D.D., Cobb, N., Kolb, T., Plaut, J., Sperry, J., West, A., Williams, D.G., Yepez E.A. (2008): Mechanisms of plant survival and mortality during drought: Why do some plants survive while others succumb to drought? New Phytologist 178: 719-739.

29. Minucci, J.M., Miniat, C.F., Teskey, R.O., Wurzburger, N. (2017): Tolerance or avoidance: Drought frequency determines the response of an N2-fixing tree. New Phytologist 215(1): 434442.

30. Moser, A., Rötzer, T., Pauleit, S., Pretzsch, H. (2016): The urban environment can modify drought stress of small-leaved lime (Tilia cordata Mill.) and black locust (Robinia pseudoacacia L.). Forests 7: 71.

31. Nurtjahya, E., Franklin, J.A. (2019): Some physiological characteristics to estimate species potential as a mine reclamation ground cover. International Journal of Mining, Reclamation and Environment 33(2): 75-86.

32. Orlović, S., Guzina, V., Krstić, B., Merkulov, Lj. (1998): Genetic variability in anatomical, physiological and growth characteristics of hybrid poplar (Populus $x$ euramericana DODE (GUINIER)) and eastern cottonwood (Populus deltoides BARTR.) clones. Silvae Genetica 47: 183190.

33. Orlović, S., Pajević, S., Krstić, B. (2002): Selection of black poplars for water use efficiency. Proceedings for Natural Sciences, Matica Srpska Novi Sad 102: 45-51. 
34. Pagter, M., Bragato, C., Brix, H. (2005).: Tolerance and physiological responses of Phragmites australis to water deficit. Aquatic Botany 81(4): 285-299.

35. Pang, C., Lo, W., Yan, R.W., Hau, B.C. (2020): Plant community composition on landfill sites after multiple years of ecological restoration. Landscape Research 45: 458-469.

36. Pietrzykowski, M. (2019): Tree species selection and reaction to mine soil reconstructed at reforested post-mine sites: Central and eastern European experiences. Ecological Engineering: X, 3: 100012 .

37. Pilipović, A., Orlović, S., Nikolić, N., Borišev, M., Krstić, B., Rončević, S. (2012): Growth and plant physiological parameters as markers for selection of poplar clones for crude oil phytoremediation. Šumarski list 136: 273-281.

38. Pilipović, A., Zalesny, R., Orlović, S., Drekić, M., Pekeč, S., Milović, M., Poljaković Pajnik, L. (2020): Growth and physiological responses of three poplar clones grown on soils artificially contaminated with heavy metals, diesel fuel, and herbicides. International Journal of Phytoremediation 22(4): 436-450

39. Pita, P., Cañas, I., Soria, F., Ruiz, F., Toval, G. (2005): Use of physiological traits in tree breeding for improved yield in drought-prone environments. The case of Eucalyptus globulus. Investigación agraria: Sistemas y recursos forestales 14(3): 383-393.

40. Pliura, A., Jankauskiene, J., Lygis, V., Suchockas, V., Bajerkevičiene, G., Verbylaite, R. (2018): Response of juvenile progeny of seven forest tree species and their populations to simulated climate change-related stressors, heat, elevated humidity and drought. iForest-Biogeosciences and Forestry 11(3): 374.

41. Prach, K. (2003): Spontaneous succession in Central-European man-made habitats: What information can be used in restoration practice? Applied Vegetation Science 6(2): 125-129.

42. Republic Hydrometeorlogical Service of Serbia (2010): Meteorological yearbook 1. Climatological data, http://www.hidmet.gov.rs/podaci/meteogodisnjaci

43. Republic Hydrometeorlogical Service of Serbia (2011): Meteorological yearbook 1. Climatological data, http://www.hidmet.gov.rs/podaci/meteogodisnjaci

44. Republic Hydrometeorlogical Service of Serbia (2012): Meteorological yearbook 1. Climatological data, http://www.hidmet.gov.rs/podaci/meteogodisnjaci

45. Robinson, G.R., Handel, S.N. (1993): Forest restoration on a closed landfill: rapid addition of new species by bird dispersal. Conservation Biology 7: 271-278.

46. Russell, K. (2003): EUFORGEN Technical Guidelines for genetic conservation and use for wild cherry (Prunus avium). International Plant Genetic Resources Institute, Rome, Italy.

47. Sena, K., Agouridis, C., Miller, J., Barton, C. (2018): Spoil type influences soil genesis and forest development on an Appalachian surface coal mine ten years after placement. Forests: 9, 780.

48. Sena, K., Barton, C., Hall, S., Angel, P., Agouridis, C., Warner, R. (2015): Influence of spoil type on afforestation success and natural vegetative recolonization on a surface coal mine in Appalachia, United States. Restoration Ecolology 23: 131-138.

49. Silva, J.C.E., Borralho, N.M.G., Potts, B.M. (2004): Additive and non-additive genetic parameters from clonally replicated and seedling progenies of Eucalyptus globulus. Theoretical and Applied Genetics 108: 1113-1119.

50. Stojnić, S., Orlović, S., Galić, Z., Pilipović, A., Kebert, M., Klašnja, B. (2011): Variability of net photosynthesis and stomatal conductance of Populus $\mathrm{x}$ euramericana cl. Pannonia rooted cuttings on two landfill sites. Proceedings from STREPOW International Workshop, 23-24 February, Andrevlje-Novi Sad, Serbia: 307-312.

51. Stojnić, S., Pekeč, S., Kebert, M., Pilipović, A., Stojanović, D., Stojanović, M., Orlović, S. (2016): Drought effects on physiology and biochemistry of pedunculate oak (Quercus robur L.) and hornbeam (Carpinus betulus L.) saplings grown in urban area of Novi Sad, Serbia. South-East European Forestry 7: 57-63. 
52. Swoczyna, T., Kalaji, H.M., Pietkiewicz, S., Borowski, J. (2015): Ability of various tree species to acclimation in urban environmentsprobed with the JIP-test. Urban Forestry \& Urban Greening 14: 544-553.

53. Taiz, L., Zeiger, E. (2002): Plant physiology, third edition. Sinauer Associates, Sunderland, MA. 690 pps.

54. Tani, A., Maltoni, A., Mariotti, B., Buresti Lattes, E. (2006): Juglans regia L. tree plantations for wood production in mining area of S. Barbara (AR). Evaluation of N-fixing accessory trees effect. Forest@ 3(4): 588-597.

55. Thomas, F.M., Gausling, T. (2000): Morphological and physiological responses of oak seedlings (Quercus petraea and Q. robur) to moderate drought. Annals of Forest Science 57: 325-333.

56. TIBCO Software Inc (2017): Statistica (data analysis software system), version 13. URL: http://statistica.io.

57. Vastag, E., Kesić, L., Orlović, S., Karaklić, V., Zorić, M., Vuksanović, V., Stojnić, S. (2019): Physiological performance of sweetgum (Liquidambar stryraciflua L.) and norway maple (Acer platanoides L.) under drought condition in urban environment. Topola 204: 17-27.

58. Vaz Monteiro, M., Doick, K.J., Lawrence, V., Albertini, A., Handley, P. (2017): Investigation into the drought tolerance of broadleaf street trees using chlorophyll fluorescence. Acta Horticulturae 1189: 427-430.

59. Veste, M., Kriebitzsch, W. (2012). Impact of drought stress on photosynthesis, transpiration and growth of black locust (Robinia pseudoacacia L.). From basic ecology to the challenges of modern society. Lüneburg, Germany. Book of abstracts. p. 137-138.

60. Vítková, M., Müllerová, J., Sádlo, J., Pergl, J., Pyšek, P. (2017): Black locust (Robinia pseudoacacia) beloved and despised: a story of an invasive tree in Central Europe. Forest ecology and management 384: 287-302.

61. Xu, F., Guo, W., Wang, R., Xu, W., Du, N., Wang, Y. (2009): Leaf movement and photosynthetic plasticity of black locust (Robinia pseudoacacia) alleviate stress under different light and water conditions. Acta Physiologiae Plantarum 31(3): 553-563. 